\title{
The Beloved Disciple
}

Ulirich Busse ${ }^{1}$

\section{ABSTRACT}

The beloved disciple

The identity of the "Beloved Disciple" in the Gospel according to John remains an unsolved problem and should therefore be investigated again. The different appearances of the "Beloved Disciple" in the Gospel are discussed, inter alia in a socialhistorical perspective. The role of the "Beloved Disciple" as literary figure could have been taken by any disciple who had faith and read the Gospel as it was intended and thus recognized the truth about Jesus Christ. As children of God such people are however included in the household of this disciple, whom Jesus loved.

In the Gospel according to John there are many puzzles to be solved. One of the oldest unsolved problems is the identity of the mysterious person with the wellsounding name of Beloved Disciple ${ }^{2}$. Down to the present day the interpreters mostly kept themselves busy with the question of his physical identity ${ }^{3}$. Since they argued that he must have been one of the intimate disciples of Jesus, they used the lists of the names of the disciples, found in the Synoptics ${ }^{4}$, to supply this mysterious person with a known historical name. The most common solution found in the history of interpretation is that he must have been John, the son of Zebedee 5 . Convinced by their own speculation, these scholars regarded the problem as solved, not investigating it any further. It can, however, also be asked, how one of the disciples of Jesus could have acquired the honorary title of 'Beloved Disciple', or which literary function has been ascribed to this disciple from chapter 13 further on.

In this paper a closer look will be taken at the above-mentioned two questions. It should be kept in mind that references to the so-called Beloved Disciple only start in chapter 13 , as was convincingly argued by $F$ Neirynck ${ }^{6}$, who wrote: "The observation made before remains valid: The first presentation of 'one of the disciples whom Jesus loved' in 13:23 and its recollection in 21:20 do not recommend the search for an allusion to the Beloved Disciple in the Gospel before chapters 13 to 20." Nevertheless, it is possible to illustrate from chapters 1-12, that the author did not intend favouring one special disciple over and against the others. E Haenchen 7 has indeed regarded this view of favouring one disciple over and against the others, as a tricky problem. However, already in chapter 11 Lazarus and his two sisters are explicitly called friends of Jesus who are loved by him 8 . In the 
introductory headline of chapter 13 , we read in the first verse that Jesus' intensely loved his own people, whom he was leaving behind in the world. The viewpoint of Haenchen reveals a modern pedagogical way of thinking which cannot be substantiated from the text itself.

The introductory verse of chapter 13 clearly refers the reader back to preceding events which on their part again identify the events narrated in chapter 13 as part of the Passion narrative9. Jesus knows - as can be seen from 12:23 - that his hour has finally come. He has chosen this hour of his own free will, since he already remarked in 10:17f10: "I lay down my life, to receive it back again. No one takes it away from me: I am laying it down of my own free will. I have the right to lay it down, and $I$ have the right to receive it back again". That this act of "laying down his life" is an expression of his love for his own, is clearly stated in 10:1511: "I lay down my life for my sheep". Consequently, in 13:1 a short, vivid summary is found of what the reader actually can and should know about the Passion of Jesus.

Out of own choice Jesus followed this brutal way. This is clearly illustrated in the following scene of Jesus washing the feet of his disciples. He is not drawn into death against his will, just as he is not forced to wash the feet of his disciples. The brief remark in verse 2 of the encouragement of Judas by the devil to betray Jesus, therefore comes as no surprise to the reader ${ }^{12}$. The urgency of the moment is stressed in this way. This urgent moment forces Jesus to react in order to stay in command of the situation. That he stays in complete command is emphatically stated in 13:19. Here the reader finds a reference to the way in which even encourages Satan to complete his work through Judas quickly. In this way the Johannine Jesus actually prepares his own death. As Joh 13:3 expresses clearly, everything was given to him by his father - also laying down his life and thus completing his mission successfully. By completing his task through his death he will be able to return to his heavenly Father. In short, with this well-formulated introduction and description of the situation, the author has laid the foundation for illuminating the two following events, which expresses three interwoven motives, namely the sovereignity of Jesus, his passion for his own and the consequences thereof for discipleship. Both scenes are also intertwined with the motives of the betrayal of Jesus and the outcome of Jesus' actions for discipleship. They are not to be read and interpreted separately, as many interpreters like to do (for example: betrayal Joh. 13:8, 10, 19; discipleship 13:8, 15, 16, 20).

The words of Jesus in 13:18 are especially relevant for our question. There the Johannine Jesus acknowledges that the betrayal and the election of the disciples are correlated. This view is supported in 13:10: "Anyone who has bathed needs no further washing. He is clean all over!..." These above-mentioned two 
motives are already linked in 6:64-70. Jesus has elected twelve disciples, but only eleven of them have been given to him by the Father.

With these insights from the first part of chapter 13 in mind, we can now turn to the second part. The second part (13:21-30) is mainly written to describe Jesus' definition of his betrayer. The characterization of the betrayer as being possessed by the devil allows Jesus moreover to claim in 14:30: "I shall not talk much longer with you, for the prince of this world approaches. He has no right over me", or further on in 16:30: "I have overcome the world". This description of the betrayer and his actions, is linked to the election to discipleship, as can be seen in Joh 6:64-70 and 13:10-11,18-19. This is especially true when read in a socialhistorical perspective.

At first it must be clarified why the Beloved Disciple was invited to sit/lie on one of the privileged places next to Jesus. The parable in Lk 14:7-11 14 supplies us with the first hint: "When Jesus noticed how the guests were trying to acquire the places of honour, he spoke to them in a parable. 'When somebody asks you to a wedding feast, do not sit down in the place of honour. It may be that somebody more distinguished than yourselves has been invited, and the host will come to say to you: Give this man your seat. Then you will look foolish when you go to take the lowest place. No, when you receive an invitation, go and sit down in the lowest place, so that when your host comes, he will say: come up higher my friend. Then all your fellow guests will see the respect in which you are held'. For everyone who exalts himself will be humbled and whoever humbles himself will be exalted". There is also another parallel in Heliodore, Aethiopica 3.10: "When we arrived at the party (the host) Theagenes gave Charicles (a high priest and philosopher) the place on the couch next to himself and treated me (as his umbra) with all respect too for Charicles' sake". ( $\mathrm{Cf}$ also Horace 2.serm.8). In these quoted texts it becomes clear that the host has the right to allocate seats for the guests. The criteria for allocating seats were the social position of the guest as well as the respect in which the host held the guest. The first lesson to be learnt from Luke 14:11 for the better understanding of the first part of John 13 is that the one who humbles himself will be taken to the place of honour. In the light of this remark, Jesus, humiliating himself will be glorified by the Father. The second lesson is that Jesus alone has the right to allocate seats, and also to allocate the seat of honour. Therefore the position of the Beloved Disciple is based on a decision of Jesus to honour him specifically. Being the crucial last meal for Jesus with his disciples, it should be asked why the Beloved Disciple was especially honoured in this way. The answer to this important question is not yet given in chapter 13 .

Returning to the tension between betrayal and election, it should be stated that election to discipleship always includes the possibility of betraying Jesus. This 
is indeed implied in chapter 6 and is realized in the person of Jude in chapter 13 and eventually done in chapter 18 later on. The question, however, remains whether the same could be true of the Beloved Disciple 15 . According to 13:28 none of the eleven, including the beloved one, knew who the betrayer would be. Not even the Scriptures could help them answer this question, since the disciples only grasped the true meaning of Scripture after the resurrection: "After his resurrection his disciples recalled what he had said, and they believed the Scripture and the words Jesus had spoken" (Joh 2:22). Although Peter actually asked who the betrayer would be, this question can only be answered by the disciples when Jesus is actually betrayed. This illuminates the understanding of Joh 20:9 where the Beloved Disciple and Peter were not able to understand the relation between what was written in the Scriptures and Jesus' resurrection ${ }^{16}$.

In chapter 19:25-27 the Beloved Disciple is mentioned again. This passage may be crucial for answering some of the questions remaining from chapter 13. Normally this impressive scene at the foot of the cross is regarded as the last extraordinary deed of Jesus ${ }^{17}$. In the hour of his death he does not forget the plight of his possibly widowed mother. He leaves her in the care of the Beloved Disciple. He actually accepts all the duties of a first-born son. In this scene the reader could find an answer to the question why the Beloved Disciple was specifically honoured by Jesus in chapter 13 . The Beloved Disciple willingly accepted the responsibility laid on him to care for Jesus' mother and could thus be seen as an example of brotherly love.

When, however, modern readers try to understand this scene through the eyes of the ancient readers, its full implication can be appreciated. Then it will be realized that the Beloved Disciple actually took upon him the duties of the other brothers of Jesus (Joh 2:12; 7:1-13) ${ }^{18}$. The duty to care for one's parents is not only clearly described in the fifth commandment of the Decalogue, but is also a common instruction of Hellenistic ethical codes. A law of Solon ${ }^{19}$ for example with the title

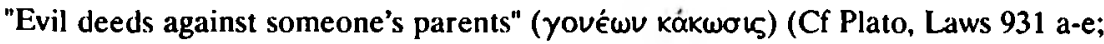
Xenophon, Memorabilies 2.2.13) ${ }^{20}$, precisely describes the punishment of children for ill-treating their parents. Ill-treatment included for instance beating one's

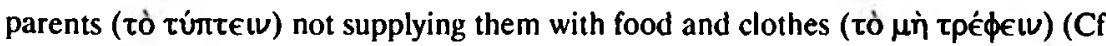

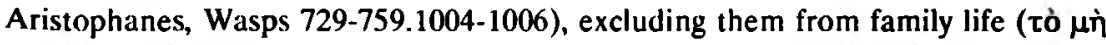

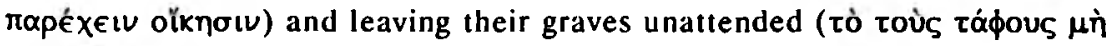

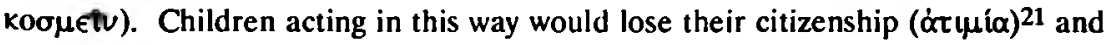
would be prohibited from entering any temple 22 . Resulting from this information two aspects related to John 19:25-27 can be better understood.

Firstly, caring for the mother of Jesus is undertaken by an adopted son of the mother on behalf of Jesus, rather than, as was commonly expected, by his blood 
brothers. The Beloved Disciple takes her into his family2.3. In chapter 7:1-13 it is stated that the blood brothers of Jesus did not believe in Him. Jesus, therefore, does not entrust his mother to his unbelieving blood brothers, although that was the law and custom. He rather entrusts his mother to the Beloved Disciple. Thus she is

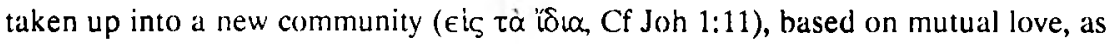
the title Beloved Disciple indicates. This also solves the problem of John 2:4 where Jesus answered his mother's request negatively: "This is no concern of mine, woman. My hour has not yet come". Jesus emphasises his loyalty to the plan (hour) of the Father which is not to be influenced by blood relationships, even that of his own mother ${ }^{24}$. These observations about the Jesus' beloved community reminds us of a description of family life by Aristotle (Nicomachean Ethics 8:1-12). In his book Aristotle especially discusses family friendship as the basis of all kinds of friendship 25 . He concludes afterwards: "Friendship, in short, is the bond of society" $(8: 12,1)^{26}$. The relevance of this statement by Aristotle becomes clearer, if one realizes that in John's Gospel friendship $(\phi \mid \lambda i \alpha)$ and love ( $\dot{\alpha} \gamma \dot{\alpha} \pi \eta)$ are used interchangeably ${ }^{27}$. At the same time it should be realized that the crucified Jesus used well-considered formulas in constructing a relationship between his mother and the disciple, namely, "Mother there is your son, and to the disciple, there is your mother". This choice of words immediately reminds the reader of the command of Jesus to love one another in chapter 13 and in the farewell speeches 28 . In this way Jesus is finishing his earthly work of love in 19:25-27 as it was anticipated in 13:1.

Secondly, it must be observed that a reference is already made in Joh 1:11-12 to a small group of people who received and accepted (elabon) Jesus and has thus become "children of God". This remark at the beginning of the Gospel supports the contention that the community of beloved people created by Jesus ${ }^{29}$ is identical with the "children of God" (Cf Joh 1:12f.). In this deeper sense the question why the Beloved Disciple is honoured by Jesus in chapter 13 is partially solved. The anonymous disciple becomes the representative of the eschatological community who is elected by God through the death and Resurrection of Christ.

From this point of view it is not surprising that the Beloved Disciple only reaches his full importance in chapter 21. Up to 20:20 the Beloved Disciple is like Peter, Martha and Thomas, representatives of all the disciples who are still not understanding the full meaning of the Scripture and the earlier words of Jesus about his Resurrection. But in chapter 21 he is first in recognizing the resurrected Jesus. As the ideal representative of the Easter community he is indeed in the position to write the true Gospel. For this reason the remark that he has leaned back close to Jesus in 21:20 refers back to 13:23. In 21:24 it is said: "He it is who wrote it and we know that his testimony is true". In this way the Johannine community supports his representative ${ }^{30}$. 


\section{RESULT}

In generating the literary figure of the Beloved Disciple, the Johannine community and the author gave expression to and thus defined their own self-understanding, where their origins lie (i.e. in Jesus) and what they should be (i.e. as his disciples). If the anthropologist Claude Levi-Strauss ${ }^{31}$ is correct in contending that the mythos of a society is expressed in a formulation of their important historical experiences transcending their day-to-day life and therefore describes their social identity, then the author of the Gospel according to John was well advised by his community to create this literary figure of an anonymous disciple and in this way expressing their own identity. Like any other institution the Johannine community requires agreedupon fictions to sustain itself.

All questions concerning the identity of the Beloved Disciple, therefore, are of such nature that any disciple could have taken his place, if only and as long as it was given to him by Jesus. Everyone who has faith in the sense intended by the author and who reads the Gospel according to John will recognize the truth that Jesus has humiliated himself for those whom the Father has given him. These have been elected by God as his children. They are included in the community of love and friendship established by Jesus in the house ( $\left.\epsilon i \zeta \tau^{\prime} \alpha i \delta i \alpha\right)$ of the disciple ${ }^{32}$, whom he loved.

\section{NOTES:}

1 This paper was read during my visit to the University of Pretoria as guest professor.

2 This indication of the early Christian tradition is not so strange as is often suggested. In Gal 2:20 Paul gives an ideal definition of discipleship: "The life I now live is not my life, but the life which Christ lives in me, and my present mortal life is lived by faith in the Son of God, who loved me (viou zov $\theta \in o v$

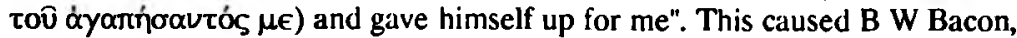
The Fourth Gospel in Research and Debate, New Haven 2 1918, 301-331.326, to remark: "In this sense Paul and whosoever has had Paul's experience...is

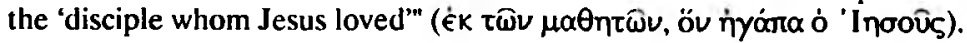

$3 \mathrm{~J}$ Moffatt, An Introduction to the Literature of the New Testament, Clark, Edinburgh 1911, 565 gives decisive ground for the traditional identification of the favourite disciple with John, the son of Zebedee: according to the Synoptists only two fraternal pairs Andrew and Peter and the sons of Zebedee are known. Only the latter could be intended in John 1:35-40.

Mk 1:16-20 par.; 3:14-19 par. 
5 This hypothesis links up with the latest commentary of D A Carson, The Gospel according to John, Grand Rapids 1991, 473, "as the most likely identity" of the Beloved Disciple.

6 F Neirynck, "The Anonymous Disciple in John I", in: Evangelica II. Collected Essays (Edited by F Neirynck) 1982-1991, 1991,617-649.648 = EThL 66) (1990) 5-37.36.

7 E Haenchen, Jolin. A Commentany on the Gospel of John, II, Philadelphia 1984, 57.233-234.236-238.

8 E Haenchen op cit, 237 thinks the Lazarus tradition suggested to the editor the idea of incorporating the figure of the favourite disciple in his Gospel. Cf however, also R Schnackenburg, Das Johannesevangelium II, Freiburg 1971, 405 .

9 R E Brown, The Gospel According to John, II, London 1970, 549; cf U Busse, "Die 'Hellenen' Joh 12,20 ff. und der sogenannte 'Anhang' Joh 21", in: F S F Neirynck III, 1992, 2083-2100. 2089.2095f.

10 Cf U Busse, "Open questions on John 10", The Shepherd Discourse of John 10 and its Context, SNTS.MS 67, edited by J Beutler/R T Fortna, 1991, 6-17.135$143,13 f$.

11 John 10:15 should be read in the light of 15:13.

12 John 6:64,70f has already reminded the reader of the early Christian tradition of the betrayal of Judas. It is here even more closely founded and led back to Satan's instigation.

13 Cf E Haenchen, op cit, 164f.

14 Further proofs from the Jewish as well as the Hellenistic literature for the right of the host to determine the seating order and for the corresponding behaviour of the guests, cf J Wettstein, Novum Testamentum Graecum I, Graz 1752, 751f.

15 The identity of "another disciple" in John 18:15 is difficult to determine. He is mostly put on a par with the "Beloved Disciple". If this is so, then it would be a further proof that this disciple should on no account be assessed differently from all the other disciples up to 20:22. It is hard to imagine that a disciple of Jesus would not sever his relations with the Jewish power-elite. Here he, however, uses his acquaintanceship to gain access to the court of the High Priest. Cf E Haenchen, op cit, 167.

16 Normally John 20:9 is interpreted in favour of the "Beloved Disciple". He has believed in spite of his ignorance of the Scriptures. Peter, however, did not. So he is superior to Peter. However, the question remains unexplained whether the faith addressed in John 20:8 was fully valid or whether it should 
only be seen as a faith which will only find its fullness in the resurrection faith. According to John 2:22 real full Christian faith without scriptural basis is hardly imaginable.

17 Cf R Schnackenburg, Das Johannesevangelium, Ill, Freiburg i. Br 1975, 319328 , offers a concise view of the different interpretation models.

18 Recently C Dietzfelbinger, Der ungeliebte Bruder, "Der Herrenbruder Jakobus im Johannesevangelium", $Z T h K 89$ (1992), 377-403, suggested that the scene below the Cross was only introduced by the author to oust the memory of James, the "unloved" brother of Christ, from the Church. In my opinion such a historically motivated speculation ignores literary function of the scene.

19 Lycophron 147; Cf. also W M Latey, Die Familie im antiken Griechenland, 1983, 118.159.171; R Flacelière, Griechenland, 1977, 112f; R P Saller, "Familia, domus, and the Roman Conception of the Family", Phoenix 38 (1984) 336-355; B M Rawson, ed., The Family in Ancient Rome: New Perspectives, New York 1986.

20 For the description of the state of affairs there was even a terminus technicus yпротрофєiv: Cf W Wyse, Isaios. The Speeches of Isaeus with critical and explanatony notes, Cambridge 1904, $219 \mathrm{f}$.

$21 \quad$ Andocides I 74.

22 Plato, Law, 881D.

23 The meaning of the expression "his own" ( $\epsilon i c \zeta \alpha \dot{\alpha} i \delta\llcorner\alpha)$ becomes clearer when one compares it with the parallel expression in John $1: 11$. There Israel is meant. There could be no doubt that also in John 19:27 a Gemeinschaftsform was meant by it. In the case of the Beloved Disciple, as only person in the narrative, the translation "family" is suggested, as figuratively aimed at the new escatological "congregation" of the "children of God", founded in the blood of Jesus.

24 Cf E Haenchen, op cit, 173.

25 Cf T Söding, "Das Wortfeld der Liebe im paganen und biblischen Griechisch, $E T h L 68$ (1992) 284-330.

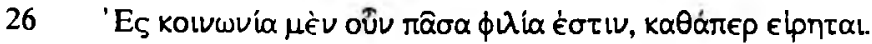

27 Cf U Busse, Johannes und Lukas: Die Lazarusperikope, Frucht eines Komnunikationsprozesses, in: Joln and the Synoptics, BEThL 101, Edited by A Denaux, 1992, 281-306.296.

28 John 13:14-17,34f; $15: 12,17$ etc. 
29 A development can be clearly determined. Jesus raises his disciples in John $15: 14 \mathrm{f}$ from the status of servants to that of friends and refers to them in John 20:17 as his brothers. Thus the basis has been established in the passion and Easter events for the escatological "Sammlungsbewegung" that results in a family-like community.

30 Cf J Moffatt, op cit, 567.

31 C Levi-Strauss, Strukturale Anthropologie, Frankfurt 1967, 226-254.

32 D Rusam, Die Gemeinschaft der Kinder Gottes. Das Motiv der Gotteskindschaft und die Gemeinden der johannneischen Briefe, BWANT 133, Stuttgart 1993, 105ff. 